\title{
ETHNIC AND RACIAL DEFINITIONS AS MANIFESTATIONS OF AMERICAN PUBLIC POLICY
}

\section{Ashton Wesley Welch \\ Creighton University}

Official definitions of race and ethnicity in American law reveal a great deal about public policy in an environment of ethnic pluralism. Despite some ambiguity over who is black or Hispanic or an Aleut, relatively few people fall between the wide cracks in the American patchwork of identity classifications. Those cracks, however, tell us a great deal about the ambivalence of the American polity toward ethnicity. ${ }^{1}$

Laws, regulation, guidelines, and judicial opinions are social artifacts that provide evidence about how a society deals with certain perceived problems. Laws are designed to serve social purposes and change as the purposes change; the specific form they may take reflects a need for congruence between laws as instruments of policy and the purposes of policy. A survey of laws on race and ethnicity suggests three different policy aims: (1) laws mandating separation and disparate treatment, (2) laws prohibiting disparate treatment, and (3) laws encouraging aggregate changes in ethnic representation. Each purpose has had a 


\section{Ethnic Studies Review Volume 26: 2}

corresponding form of definition. If the purpose of a law is to mandate diverse treatment of individuals based on race or ethnicity, the law must be quite precise about who falls into which category, because an administrator is expected to make clear distinctions in individual cases. Hence, it is not surprising that laws on race became more precise following the abolition of slavery, especially as segregation hardened in the post-Reconstruction South, and that segregation laws contained quite precise definitions. On the other hand if a law is intended to prevent differential treatment, there is much less need for specifying who is what; in fact, legislators are likely to be very uncomfortable about definitions. Finally, when laws are intended to mandate aggregate changes in ethnic composition in social institutions -employment, education, or political participation, for examplethere is a need for workable generalizations upon which aggregate data can be collected, but not a need for accurate determination in each individual case. Hence, loose definitions that work more or less well (Hispanic surnames, for example) may be all that is considered necessary to achieve the overall goal, in spite of their under- and over-inclusiveness in individual cases.

These three models reflect, roughly, the historical development of American laws on race and ethnicity, but the correspondence is punctuated with transitions and inconsistencies. Our interest is in the policy implications of each model, rather than in trying to impose or infer a strict sequential order. But public policy is not a "seamless web" or a rational ordering of rules. Just as the American polity and decision-making process is fragmented, disorderly policy results reflect the inconsistent aims of competing communities. The current peculiar mixture of elaborate guidelines and awkward definitions reflects the society's ambivalence between non-discrimination (color-blind) and affirmative action (color-conscious) policy goals. Indeed, it is the simultaneous existence of the second and third models which makes the contemporary American approach to race and ethnicity so complex.

Furthermore, a close look at ethnic policy reveals the importance of "who is what,"but also of "which groups counts." Why do African Americans and Hispanics count as minorities for purposes of the 1965 Voting Rights Law but not Hasidic Jews? Why 


\section{Welch-Definitions}

are there affirmative action programs for Asians and Hispanics but not for Arabs and Irish? Obviously it is a matter of perceived needs and priorities. There is absolutely no logic in dividing America's population into White, Black, Hispanic, Native American, and Asian, as though the terms were exclusive and comprehensive; the distinction is purely a matter of convenience. For some purposes, a simple separation may be all that is necessary -"white" and "nonwhite." For other purposes we separate out the so-called "white-ethnics" and count Southern and Eastern Europeans as minorities. At some times Asians are classified together; in World War II, it became crucial to distinguish Japanese from all other Asians. In some parts of the country "Hispanic" means Mexican-American, in other parts Cuban or Puerto Rican, and in other parts there are too few to make a difference. In most of the United States, "black" will do to delineate African Americans from Whites; in parts of the East coast, it can be useful to distinguish "native" Blacks from West Indian Blacks. In most of the states, Alaskan natives are just that; in Alaska public policy purposes can require more precise categories. A similar paradigm can be posited for Hawaii between Hawaiians and Native Hawaiians. In short for public policy purposes ethnicity is politically defined, and ethnological precision simply does not matter. Words, like tools, reflect the needs of the people who use them; where all we need is a meat axe, we are not likely to find surgical scalpels.

II

By far the most extensive use of race and ethnicity in American law has been to enforce racial separation and to perpetuate a complex social hierarchy. Such laws seem to serve two closely related purposes. Some are intended to ensure separation-antimiscegenation laws are the most obvious; in addition, laws requiring racial segregation in schools, facilities of transportation and accommodation are of this type. Second, laws may be aimed at preserving the inferior status of minorities by mandating, inferior treatment -for example, laws requiring certain acts of social deference by Blacks towards Whites, laws preventing Blacks from attending certain schools and universities, voting, serving on juries or entering certain professions, or laws 


\section{Ethnic Studies Review Volume 26: 2}

prohibiting Asians from owning land served this purpose. Given the pre-eminence of race in the American experience, the great bulk of both kinds of law deal with the relationship between whites and nonwhites.

Laws stipulating the proper relationship between the races were adopted very early in the colonial period. These formative policies reflect a quite unself-conscious belief in white superiority and an acceptance of hierarchy as part of the nature of things. The early status of Africans was ambiguous; most arrived as slaves, but African slavery was not recognized as a legal institution until around 1640. The first such laws, therefore, were concerned with regulating the social status of blacks and creating the institutions of slavery. By the first years of the eighteenth century, extensive codes regulated occupation, residence, and marriage. The Revolution did not create any dramatic change in this kind of law, except that they became more elaborate as the practice of slavery became institutionalized in Southern and border states. As slavery was abolished in the North it was replaced by segregation laws. Reconstruction changes were extremely shortlived. The most extensive use of racial definitions in American law is a post-Reconstruction phenomenon, beginning with the Black Codes and elaborated more extensively in a half century of Jim Crow laws, which persisted well past the midpoint of the $20^{\text {th }}$ century.

Seemingly ignorant of the expanding process of mestizaje much less of the mixing of Africans and Europeans already rooted in Spanish America, at the beginning of their settlements in America the English did not foresee any need to define race; it seemed too obvious to need definition. Africans begot Africans in the New World as in the old in the same way that English begot English in both worlds, and racial distinctions were seen as a n unambiguous part of the order of nature, but the occurrence of unions between Blacks and Whites in British America created a need for racial definitions. The first response was the adoption of anti-miscegenation laws; they were already on the books in Maryland and Virginia by the 1660 s. The majority of the colonies enacted statutes designed to outlaw not only marriage, but also any sexual relations between Whites and others. Allowing for variation from colony to colony, such statutes also provided for 
punishing ministers who conducted interracial marriage ceremonies, enslavement or banishment of white women who entered proscribed marriages, payment of double fines by those who engaged in interracial fornication, and placement of the offspring of interracial sex into the slave status of the mother if the mother was black and into enslavement if the mother was white. In general the penalty was far more severe on the black partner than on the white one, and, needless to say, extra-legal enforcement was far more Draconian than anything found in the codebooks. $^{2}$

Laws were powerless in the face of human nature. Interracial unions continued to occur and thus forced EuroAmericans to reconsider their understanding of race. According to a chronicler of the colonial period, Virginia was "swarming with mulattoes." What had seemed simple and unambiguous became clouded by gradations and complexities. The response to this complexity displayed two contradictory impulses, a simultaneous desire both to recognize and to deny these ambiguities. On the one hand almost every state wrote into its laws some official definition of the gradations of race; on the other hand the same laws obliterated any significance of those gradations by collapsing the categories back to "white" and "nonwhite." The gradations ranged from the use of the term mulatto to define persons of black and white parentage to the more elaborate Louisiana code that delineated degrees of whiteness through seven previous generations. ${ }^{3}$

Fluctuations in the U.S. Census racial classifications are especially instructive. They remind us that the definition of who was black has been determined from the beginning by Whites. Even though the colonies had legislated degrees of blackness and Whites and Blacks had been identified in every census, beginning with the first one in 1790, it was only in 1850 with the Seventh Census, that the Bureau of the Census made a distinction between mulattoes and Blacks. The 1850 Census classified the population as white, black, or mulatto, although there were no instructions for defining "mulatto." In contrast to the modern census a person did not identify his or her category; rather it was left to the enumerator to determine. In the 1870 and 1880 censuses mulattoes were officially defined to include 


\section{Ethnic Studies Review Volume 26: 2}

"quadroons, octoroons, and persons having any perceptible trace of African blood." The interest in specificity reached its height in the 1890 Census. The enumerators were instructed:

Be particularly careful to distinguish between blacks, mulattoes, quadroons, and octoroons. The word 'black' should be used to describe those persons who have three-fourths or more black blood; 'mulatto,' those persons who have three-eighths to five-eighths black blood; 'quadroon,' those persons who have onefourth black blood; 'octoroons,' those persons have one-eighth or any trace of black blood. 4

It is not at all clear how enumerators were expected to gather this information, and its useless complexity was abandoned after 1900 in favor of the simplified classifications, "black" and "mulatto." The mulatto category was dropped in 1920, and from that year forward anyone with any perceptible Black African ancestry was simply defined as Negro. These determinations were made by census enumerators until the 1960 census, which then rested the determination with the head of household responsible for filling out the census form. ${ }^{5}$

These examples demonstrate an inconsistency of racial policy within the first model. States were making quite explicit and elaborate racial distinctions and then negating them by treating persons of all gradations as black. North Carolina, for example, carefully defined mulattoes as persons with one-sixteenth Negro ancestry and then proceeded to classify mulattoes as Negroes for the purposes of its law. 6 Louisiana is quite instructive. Recall the detailed provisions in the state's law. Also recall that Plessy $v$. Ferguson, the case in which the Supreme Court gave constitutionality to the doctrine of separate but equal, involved a Louisiana law which required racially separate railroad accommodations, and that Homer Plessy's challenge was based in part on his objection to Louisiana's classifying him as black since he was seven-eighths white. ${ }^{7}$ Clearly the elaborate distinction of Louisiana's laws served no ascertainable purpose.

The general pattern of these laws is quite clear. The real interest was not in determining who was black but who was not white. What emerged was an algorithm for distinguishing Whites and nonwhites. The Alabama code is typical: ". . . the 
word "negro" includes mulatto. The word "mulatto" or term "person of color" means a person of mixed blood descended on the part of the father or mother from negro ancestors, without reference to or limit of time or number of generations. ${ }^{8}$

Perhaps the clearest attempt to make a simple distinction between white and nonwhite is found in the Georgia code, which provides that

All Negroes, mulattoes, mestizoes, and their descendants, having any ascertainable trace of either Negro or African, West Indian, or Asiatic blood in their veins, and all descendants of any person having either Negro or African, West Indian, or Asiatic Indian blood in his or her veins shall be known in this state as persons of color. and

The term 'white person' shall include only persons of the white or Caucasian race, who have no ascertainable trace of either Negro, African, West Indian, Asiatic Indian, Mongolian, Japanese, or Chinese blood in their veins. No person, any of whose ancestors [was] ... a colored person or person of color, shall be deemed to be a white person. 9

Since "Chinese, Japanese, Mongolians ..." were not white, it is no surprise to find the Supreme Court upholding local decisions to assign a Chinese student to a Negro school.10 The "white" classification remained always the most exclusive.

Above all the attempt to be precise reflects the needs of a society that classifies people according to race. Laws that required separation and disparate treatment were intended to be applied to individuals in specific instances. Segregation laws provide an excellent example. If railroad conductors were to know whom to assign to which railroad cars, they needed fairly precise guidelines for knowing whom to seat where. Indeed a mistake was a cause for collecting damages. ${ }^{11}$ If laws were to prevent Blacks or Asians from attending white schools, serving on juries, holding certain federal jobs, patronizing places of public accommodation, or regulating issues of family and criminal law, then officials needed guidelines that could be applied in individual cases. Mathematical or scientific certainty of degrees 


\section{Ethnic Studies Review Volume 26: 2}

of race was not only necessity but it was presumed to be possible. By virtue of judicial pronouncement, a litigant could enter a courtroom as a black person and leave as a mulatto or white person. For example in Jones $v$. Commonwealth, Isaac Jones successfully appealed his sentence of almost three years for marrying a white woman contrary to "the peace and dignity" of the Commonwealth of Virginia whose law forbade marriage between "Negroes" and Whites and defined a Negro as a person with "one-fourth or more negro blood." Mr. Jones asserted that he had less than one-quarter black blood. Although the court found that Jones was a "mulatto of brown skin" and that his mother was a "yellow woman," it found that the Commonwealth was unable to establish the "quantum of negro blood in his veins." The precept, "anyone who is not white is colored," although imperfect, did minimize ambiguity.

Clearly, most of the laws precisely defining race are artifacts of the segregation era. But since law is not a "seamless web," we find vestiges of these kinds of definition in an era when their policy function is far from obvious. Two decades ago, a dispute arose over Louisiana's law requiring anyone of more than 1/32 African descent to be classified as black. Louisiana's $1 / 32$ law is of relatively recent vintage; until 1971 the law had relied on "common repute" for racial classifications; the return to the older form was intended to eliminate racial classifications by gossip and inference. In September of 1982 Mrs. Susie Guillory Phipps, having discovered that her birth certificate classified her as Colored, petitioned to have her classification changed to White, to reflect "her true status as a Caucasian." The state objected and produced an eleven-generation genealogy tracing Mrs. Phipps's ancestry back to an early eighteenth-century black slave and a white plantation owner. Mrs. Phipps's argument centered on the inappropriateness of applying racial designations to individuals accurately and the impossibility of determining racial ancestry precisely to meet judicial standards of evidence. In this curious case and the anachronistic issue it represents the U.S. Supreme Court sided with Louisiana. ${ }^{12}$

Although the black/white distinction has been most pervasive, clearly Blacks have not been the only nonwhites. The definition of Asian-Americans has a history of its own, centering 
largely on naturalization and immigration challenges. The Naturalization Act of 1790 provided that only free white persons could become citizens, and in spite of numerous changes over the years, including providing for the naturalization of persons of "African nativity," Asians continued to be ineligible for citizenship until the Second World War. In the late nineteenth century both Chinese and Japanese did enter the country, but they could not be naturalized to be citizens unless they were "white." Asians sought naturalization under the existing standards, but always as Whites. For example, in 1878 Chinese were denied citizenship because "a native of China, of the Mongolian race, is not a white person." Then in 1922 a legally resident Japanese petitioned for naturalization, arguing that he met the color requirement. Associate Justice George Sutherland, speaking for the Supreme Court, explained that "white" did not refer to color but to membership in the Caucasian race. A few months later in the case of a "Hindu" appealing the denial of his petition for citizenship, again speaking for the Court, the same Justice Sutherland was unimpressed by the fact that Indians are Caucasians; "white," he declared, refers to color, not to race. Thus within the space of one year the Court had ruled both that "white" meant the Caucasian race and not color and that it meant color and not the Caucasian race. In both cases the Asian petitioners were denied citizenship with a naturalized immigrant from England writing the majority decision. ${ }^{13}$

Judges even ventured to involve themselves in the question of proportion of nonwhite "blood" which might render one ineligible for citizenship. In 1934 Justice Benjamin Cardozo, speaking for a unanimous Court, offered the following dictum regarding non-Caucasians:

Nor is the range of the exclusion limited to persons of the full blood. The privilege of naturalization is denied to all who are not white (unless the applicants are of African nativity or African descent); and men are not white if the strain of colored blood in them is a half or a quarter, or, not improbably, even less, the governing test always being that of common understanding.

Twenty five years earlier, another federal judge had ruled that a "person, one-half white and one-half of some other race, belongs 


\section{Ethnic Studies Review Volume 26: 2}

to neither of those races, but is literally a half-breed." 14

Following the rulings that Asians were racially ineligible to become American citizens, Congress in 1924 prohibited the immigration of "persons ineligible for citizenship." The Chinese had been denied entry previously by the Chinese Exclusion Act of 1882 , and Japanese immigration had been severely limited by the Gentlemen's Agreement with Japan in 1907. Furthermore those Asians already resident in the country were subjected to segregation in schools, hospitals, and housing and to exclusion from the mainstream of employment and public affairs. The removal of some 250,000 Mexican-Americans and perhaps an equal number of Mexicans to Mexico during the Depression and the internment and relocation of Japanese-Americans during the Second World War exemplified this kind of policy. Even when explicit racial classifications were all but removed from the law in the Immigration and Naturalization Act of 1952, immigration quotas accomplished the same result by severely restricting the number of nonwhites allowed to enter the country.

To many Americans Southern and Eastern Europeans were nonwhites. The great waves of immigration during the decades surrounding the turn of the twentieth century created a patchwork of ethnic minorities and complex patterns of ethnic discrimination; however, except for immigration matters such discrimination did not become embodied in official policy. Distinguishing the various kinds of "white ethnics" in a legal code would have been infinitely complex and politically disastrous; moreover, it was unnecessary. Ethnic separation and disparate treatment could thrive quite well as the unofficial practice of both public and private institutions.

The characterization of the Hispanic population has shifted from nationality to race to ethnic group. In 1821 when Mexico won its independence from Spain, Americans did not consider Mexicans to be a separate race; they were white, and until 1930 the U.S. Census Bureau's interest in Mexican-Americans, as in most immigrants, was in counting the foreign-born population. The classification "Mexican" was used to designate only those persons born in Mexico or their children. In 1930, however, the Census Bureau placed the term, "Mexican," under the general rubric "other races," which also included Native Americans, 
Negroes, and Asians. In one stroke Mexicans became another race, hence nonwhites. This was the first time that a nationality was formally recognized as a race. In addition census enumerators were instructed to classify as Mexicans all persons of Mexican ancestry regardless of number of generations in the United States. This designation evinced unfavorable reaction from the government of Mexico as well as the U.S. State Department, and was replaced in 1940 by a classification based upon the Spanish language -whether Spanish was the mother tongue or not. Hispanics thus became a linguistic minority. Coding instructions of the 1940 Census directed that "Mexicans were to be listed as White, unless they were definitely Indian or some other race than White." In 1950 the Spanish surname definition was introduced, and at the same time, such people were now classified among Whites -"white persons of Spanish surname." Mexicans were now white ethnics. Other Latinos also became Whites consistent with the 1960 Census which provided that "Puerto Ricans, Mexicans or other persons of Latin descent [were] to be classified as 'White' unless they were definitely Negro, Indian, or some other race." The reclassification was significant for some groups: for example, during the Second World War the U.S. military classified Puerto Ricans as another race, which translated to mean they were not white. Under that policy, the U.S. Army had placed Puerto Ricans in segregated facilities, even on the island, and the U.S. Navy refused to accept any of them into its ranks.

In the meantime states also struggled with categorizing Latinos. For example, guided by the Encyclopedia Britannica which held that approximately one-fifth of Mexicans were Whites, approximately two-fifths were Indians, and the balance had African, Chinese and Japanese heritage, an Indiana appellate court ruled, in Inland Steel Co, v. Barcena, that a Mexican was not necessarily white. In contrast, Independent School District v. Salvatierra (1930) and in Hernandez v. State (1952), Texan courts ruled that Mexicans are white.

By the middle of the twentieth century this intricate patchwork of racial and ethnic delineations and the policies they implied were long overdue for rethinking. Global events, including the horrific racial policies of Nazi Germany and 


\section{Ethnic Studies Review Volume 26: 2}

apartheid South Africa, nationalist movements in the colonial world, and ideological competition for the allegiance of the newly emergent states, as well as domestic developments led to the evolution of a new model of minority relations policy.

\section{III}

Over a period of perhaps twenty-five years (roughly from the 1940s through the 1960s) the focus of laws on race and ethnicity changed from an intention to mandate separate and disparate treatment to the forbidding of separation and disparate treatment. Segregation laws were repealed or ruled unconstitutional; federal executive orders, administrative guidelines, and statutes were enacted to forbid discrimination on the basis of race, color, or national origin. Private employers, schools, and other institutions erased racial identifications from their records, often replacing them with covert codified substitutions. Race and ethnicity became taboo subjects: one was no longer Mexican, but a "person of Spanish descent," no longer a Jew, but a "person of the Hebrew persuasion." Many felt uncomfortable with Negro; "black" or Afro-American or African American became preferable. In the same way, "Native American" rose as an alternative to Indian. Clearly consciousness of race and ethnicity had not diminished; on the contrary it was probably enhanced by the "civil rights" movement.

The 1964 Civil Rights Act is the most important national policy statement of this type. Title II forbids discrimination in places of public accommodation on the basis of race, color, national origin, or religion; Title VI does the same thing for employment, adding sex as a prohibited classification. Religion is briefly defined in the Act, but not one word indicates what race, color, or national origin mean. We suggest two explanations for this silence -both plausible and both probably accurate. First, the silence indicates, as already suggested, a real discomfort with these classifications in an era in which the thrust is to get away from classifying. More significantly it is not particularly important to define race and ethnicity precisely in a law which forbids discrimination on the basis of race and ethnicity. If restaurant owners are forbidden to refuse service on the basis of race, it is not important that they know who is or who is not black. Nor 
need law enforcement officials know.

A statute, of course, is only a general policy statement; for its details and its applications, we need to consult judicial interpretations and the guidelines of agencies such as the Equal Employment Opportunity Commission (EEOC) and the Office of Management and the Budget (OMB). As expected, race is virtually undefined. EEOC guidelines on race indicate only that "An employee may be included in the group to which he or she appears to belong, identifies with, or is regarded by the community as belonging."15 The term "national origin," however, did seem to raise some provocative definitional issues. Simply prohibiting discrimination on the basis of national origin failed to give adequate direction to employers. To begin with the words do not mean exactly what they say. "National origin" does not mean the individual's own national origin; it refers to the national origin of his ancestors -roughly, to his ethnicity. ${ }^{16}$ This ambiguity engendered considerable litigation because (despite the words of the law) it is quite permissible to exclude foreign-born non-citizens from numerous kinds of employment opportunities, ${ }^{17}$ as some members of the military discovered as recently as during the U.S. occupation of Iraq.

It took a number of years to develop an understanding of "national origin" discrimination, and numerous questions remain unanswered. The EEOC does not provide a clear definition of "national origin," but an unissued version of a guideline draft suggests the following:

Discrimination based on national origin shall be defined broadly to mean: (1) Discrimination based on the country from where an individual or his forebears came; (2) Discrimination against an individual who possesses the cultural or linguistic characteristics common to an ethnic or national group. ${ }^{18}$

The elements of "cultural and linguistic characteristics" necessitated further distinctions. EEOC guidelines were elaborated by rules prohibiting the following practices:

(1) Denial of equal opportunity to persons married to or associated with persons of a specific national origin; (2) Denial of equal opportunity because of membership in lawful organizations identified with or seeking to pro- 


\section{Ethnic Studies Review Volume 26: 2}

mote the interests of national groups; (3) Denial of equal opportunity because attendance at schools or churches commonly utilized by persons of a given national origin; (4) Denial of equal opportunity because one's name or that of one's spouse reflects a certain national origin. ${ }^{19}$

Furthermore English language requirements, and height and weight requirements, if not job-related, may unlawfully discriminate against national minorities. Neither may an employer use appearance as a reason for refusing employment if appearance is associated with a particular national group. Nor may ethnic harassment (ethnic jokes and slurs, for example) be permitted to create a hostile work environment for a minority employee.

All of these guidelines are phrased as "Thou Shalt Not"; they attempt to tell employers what they may not do. Behind this form is a particular view of discrimination. It reflects a belief that discrimination is a discrete, individual, act which can be prohibited as simply as any other crime. Once these disagreeable practices were eliminated the remaining condition would be one of equal opportunity. This notion reflects a "melting pot" view of the American dream, in which race and ethnicity were to become irrelevant to individual achievement. Defining ethnicity was unimportant -even repugnant- because ethnic distinctions should be unimportant. This was a compelling vision; for many, it remains so. As a guideline for public policy, however, it did not work.

Discrimination turned out to be not a discrete act, but a systemic process. Racial and ethnic classifications could be obliterated from the record, and their effects remain untouched. Countless other characteristics -wealth, residency, educational attainment, English language proficiency, for example- could easily stand in the place of race or ethnicity, and produce the same exclusions. As early as the mid-1960s observers began to realize that we might need racially or ethnically conscious solutions to racial and ethnic problems. In the words of Associate Justice Harry Blackmun, "In order to get beyond racism, we must first take account of race. There is no other way. And in order to treat some persons equally, we must treat them differently. We cannot -we dare not- let the Equal Protection Clause perpetuate 
racial supremacy." Consequently, as the policies changed, so did the ways of defining race and ethnicity. 20

IV

Since discrimination is systemic, it needs systemic solutions. Above all solutions required not only individual prohibitions but policies aimed at affecting the opportunities of minorities in the aggregate. This development can be observed most clearly in the employment and political policies, because both affect large numbers of people, and because they have produced detailed and profuse guidelines, regulations, and judicial decisions.

The simple kind of discrimination-the individual, intentional act which the 1964 Civil Rights Act sought to prohibit-turned out to be very difficult to prove. The complainant assumes the burden of proving that the employer intended to discriminate. A clever employer with any sophistication can obscure such intent by adopting apparently neutral criteria which have a racially or ethnically disproportionate impact. Hence, to combat discrimination in practice, it becomes important to focus not on intent, but on the impact of an employment practice. Employment criteria (tests, educational attainment, English language, for example) which adversely and disproportionately affect ethnic minorities are considered "inherently suspect"; their use shifts the burden of proof from the complainant to the employer, making the employer responsible for defending the validity of his criteria by demonstrating their relevance to actual job performance. ${ }^{21}$

Not only in employment but also in voting, education, and other areas, policy developments reflect a shift in emphasis from the individual act of intentional discrimination to a focus on the aggregate effect of a practice and the designing of aggregate solutions. The 1965 Voting Rights Act, as amended, was adopted explicitly because earlier attempts to remedy discrimination through individual challenges had proven unsuccessful. Voting discrimination against minorities, ranging from ingenious legal subterfuges to physical harassment, had long been an intrinsic element of the political process in many areas. The Act outlawed the devices that had been designed to exclude minorities from the franchise (poll taxes and literacy tests, for example). More important, it provided that where voter registration was below 


\section{Ethnic Studies Review Volume 26: 2}

fifty percent, and where such devices had been used, the low registration would be presumed to have resulted from intentional acts, and would thus trigger special scrutiny of any changes in electoral procedures by the Justice Department. ${ }^{22}$ As with federal employment guidelines the triggering mechanism is disproportionate impact on minorities, and the goal is to produce aggregate results. From aggregate remedies it is only a small step to aggregate programs such as affirmative action, which mandate that some preference be given to minority candidates in order to enhance the aggregate representation of these groups in the workplace, school, or voting district.

This change in policy raises some fascinating issues. In order to show disproportionate impact, one must be able to collect some comparative data about the proportions of minority members in the challenged institution and in the population as a whole. Thus it becomes important again to have definitions of race and ethnicity. Furthermore, the kinds of definitions needed are different from those required previously. One no longer needs individually precise algorithms but workable heuristics for collecting aggregate data. Who can claim minority status now becomes crucial. Politically it becomes extremely significant who counts as "white" and who counts as a minority and how the minorities are grouped together. In the end pursuing a technical question like definitions of race and ethnicity leads to some of the fundamental issues of American pluralism.

The ability to make a negative impact claim depends upon the availability of ethnic data. Hence, which groups are included in which categories and how the groups are defined become politically important. Race remains the most crucial. Whereas previous definitions of race sought some kind of objective criterion, contemporary models rely much more heavily on self- or community-identification. The Census Bureau prefers self-identification, augmented by some simple guidelines in case of ambiguity:

The concept of race as used by the Census Bureau reflects self-identification by respondents; it does not denote any clear-cut scientific definition of biological stock. Since the 1980 census obtained information on race through self-identification, the data represent self- 
classification by people according to the race with which they identify. For persons who could not provide a single response to the race question, the race of the person's mother was used; however, if a single response could not be provided for the person's mother, the first race reported by the person was used. This is a modification of the 1970 census procedure, in which the race of a person's father was used. . . .

The category 'Black' includes persons who indicated their race as Black or Negro, as well as persons who did not classify themselves in one of the specific race categories listed on the questionnaire, but reported entries such as Jamaican, Black Puerto Rican, West Indian, Haitian, or Nigerian. ${ }^{23}$

The most detailed definitions available on race and ethnicity are those used in Federal Contract Compliance, which requires employers to maintain records on the race and ethnicity of job applicants. "The Glossary of Terms" in the compliance manual includes the following definitions:

American Indian or Alaskan Native -A person with origins in any of the original peoples of North America who maintains cultural identification through tribal affiliation or community recognition.

Asian or Pacific Islander -A person with origins in any of the original peoples of the Far East, Southeast Asia, the Indian sub-continent, or the Pacific Islands. This includes, for example, China, Japan, Korea, the Philippine Republic, and Samoa.

Black, not Hispanic origin -A person with origins in any of the black racial groups of Africa who is also not of Hispanic origin.

Hispanic -A person of Mexican, Puerto Rican, Cuban, South American, or Spanish culture or origin, regardless of race.

White, not of Hispanic origin -A person with origins in any of the original peoples of Europe, North Africa, or the Middle East who are not of Hispanic origin. ${ }^{24}$

Behind these definitions lies a subtle theory of ethnicity as a geographic phenomenon. Each definition is phrased in terms of the 


\section{Ethnic Studies Review Volume 26: 2}

geographic origins of the person's ancestors. The notion that an individual has "origins" other than his or her place of birth appears vague if not mystical. Moreover it seems unsatisfying to conceive of ethnicity only in terms of the national roots of one's ancestors. Some groups-Irish-Americans, or MexicanAmericans-may indeed think of their ethnicity as related to the country of their ancestors' origin; however, such a conceptualization gives great consternation to ethnically conscious Jews of diverse geographical "origins." Secondly, it seems to misconceive the essential phenomenon of black ethnicity. "Origins in Africa" are probably not at the heart of the subjective experience of black ethnicity as much as perceptions of a shared history in America and obvious distinguishing characteristics such a color.

Furthermore the obvious vagueness of these definitions is extremely instructive. It is quite easy for persons of mixed ancestry to fall through the cracks in the definition, the creation of the Biracial category in the 2000 Census and in a number of recently enacted state laws notwithstanding. For example how does one classify a person of mixed Asian and European parentage? The answer is that it does not really matter. Since these guidelines are used for collecting aggregate data and the making of aggregate policy, no treatment of any individual should depend on whether he or she is classified Asian or White. Occasionally, there may be infuriating injustices, such as intentional misclassifications in order to take advantage of minority-sensitive programs. But the point of these guidelines is really not to assure individually equal treatment (that goal is still handled under the non-discrimination model) but to promote general changes in minority representation.

One is reminded of Aristotle's admonition not to demand more precision than the subject requires. Race, biologists suggest, is purely a statistical concept which makes no sense as applied to individuals. Group definitions therefore become the only kind possible. Hence the search for individually applicable definitions would be futile. Ethnicity also refers to the shared attributes of groups and thus characterizes individuals only in their group relations.

If one is going to challenge and to change practices based on their impact on minorities, comparative data must be avail- 
able. But data is collected about some groups and not others, and the way that the human population is classified is as politically significant as it is arbitrary. Certainly no anthropologist could justify treating Hispanic as parallel with Black, White, and Asian. The point is that Hispanics are listed separately because they have a unique position in the American experience, and thus are regarded as minorities. We can understand the importance of this inclusion by observing its political significance in a concrete instance. In 1973 the city of Denver was accused of segregating its public schools. Whether the charge could be substantiated depended upon whether Hispanic students were counted as white or nonwhite for the purpose of school assignment. If Hispanic students were counted as white, the school district did not appear to be segregated, but if they were considered minorities (along with blacks), the system appeared quite segregated. The Supreme Court's handling of this issue gives an idea of its policy significance.

[A] word must be said about the District Court's method of defining a 'segregated' school. Denver is a tri-ethnic, as distinguished from a biracial community. The overall racial and ethnic composition of the Denver public schools is $66 \%$ Anglo, $14 \%$ Negro, and $20 \%$ Hispano. The District court in assessing the question of de jure segregation in the core city schools, preliminarily resolved that Negroes and Hispanos should not be placed in the same category to establish the segregated character of the school . . . . Later, in determining the schools that were likely to produce an inferior educational opportunity, the court concluded that a school would be considered inferior only if it had a "concentration of either Negro or Hispano students in the general area of 70 to $75 \%$. . . .

We conclude ... that the District court erred in separating Negroes and Hispanos for purposes of defining a 'segregated school.' We have held that Hispanos constitute an identifiable class for purposes of the Fourteenth Amendment. But there is also much evidence that in the Southwest Hispanos and Negroes have a great many things in common .... [T] hough of 


\section{Ethnic Studies Review Volume 26: 2}

different origins, Negroes and Hispanos in Denver suffer identical discrimination in treatment when compared with treatment afforded Anglo students. In that circumstance, we think petitioners are entitled to have schools with a combined predominance of Negroes and Hispanos included in the category of 'segregated' schools. ${ }^{25}$

Not only who is a minority but also who is not a minority is significant. Since "minorities," for all practical purposes, are limited to blacks, Asians, and Hispanics, it is virtually impossible for so-called "white ethnics" to make adverse impact claims. Because separate figures are not kept for Poles, Italians, Jews, Arabs, etc., they lack the comparative data to show that they have been disproportionally excluded from employment or other opportunities. Joseph Alegretti, an ethicist and labor law specialist, writes:

[D] isparate impact requires statistical proof of the effect of the effect of an employment practice on the plaintiff's group in comparison to other groups. Compiling the needed statistics is not a problem for black or female or Spanish-surnamed plaintiffs. However, the absence of necessary statistical information presents a nearly insurmountable barrier to a person of Polish, Irish, or Russian ancestry who wishes to bring a disparate impact case. The reason for the dearth of information is simple: no governmental agency requires employers to compile data on the national origin of employees. The EEOC's reporting forms such as the EEO-1 limit their categorization to five groups: black, Hispanic, Asian, American Indian, and white. Persons of European or North American origin are classified as white. The Uniform Guidelines on Employee Selection Procedure of the Office of Federal Contract Compliance Programs (OFCCP) affirmative action guidelines . . . adopt the same classified scheme.

Likewise, the 1970 census included questions on race and Spanish origin, but the only question concerning other ethnic groups was one that asked the country of origin of one's parents. Thus the Census 
Bureau does not compile the ethnic identity statistical information that is necessary to bring a disparate impact claim. 26

One of the more intriguing instances of this morass was raised by an attempt under the 1965 Voting Rights Act to redraw the electoral district boundaries in New York City in order to enhance the voting strength of blacks and Puerto Ricans. To do so a predominantly Hasidic electoral district was split and its voting strength seriously eroded. The Supreme Court upheld this procedure as a legitimate effort to correct the disabilities suffered by minorities. Hasidim may be a minority, but for purposes of the Voting Rights Act they were simply "white." 27

Considerable controversy also arose over the inclusion of Asian-Americans among disadvantaged applicants in the University of California special admissions program challenged in the Bakke case. In spite of ethnic discrimination AsianAmericans achieved high rates of admission to professional schools even under regular admissions procedures; hence, some argued that their inclusion in the special admissions program unfairly disadvantaged other minorities.

Clearly there is no simple answer to deciding which minorities are minorities in American society. The difficulty of selecting some minorities in a pluralistic setting was quite well stated in the Bakke opinion by Justice Powell:

[I]t was no longer possible to peg the guarantees of the Fourteenth Amendment to the struggle for equality of one racial minority. During the dormancy of the Equal Protection Clause, the United States had become a nation of minorities. Each had to struggle-and to some extent still- to overcome the prejudices not of a monolithic majority, but of a "majority" composed of various minority groups of whom it was said-perhaps unfairly in many cases-that a shared characteristic was willingness to disadvantage other groups. As a nation filled with the stock of many lands, the reach of the Clause was gradually extended to all ethnic groups seeking protection from official discrimination ....

The concepts of 'majority' and 'minority' necessarily reflect temporary arrangements and political judg- 


\section{Ethnic Studies Review Volume 26: 2}

ments .... [T] he white 'majority' is itself composed of various minority groups, most of which can lay claim to a history of prior discrimination at the hands of the state and private individuals. Not all of these groups can receive preferential treatment and corresponding judicial tolerance of distinctions drawn in terms of race and nationality, for then the only 'majority' left would be the new minority of White Anglo-Saxon Protestants. There is no principled basis of deciding which groups would merit 'heightened judicial solicitude,' and which would not. 28

The Bakke decision is profoundly ambivalent. On the one hand the Court plurality rejects the contention that any group of minorities can lay claim to permanent minority status and special solicitude at the expense of individual fairness. On the other hand the plurality recognizes that racially and ethnically sensitive programs are necessary to achieve the social diversity that a pluralist society purports to value. Both of these positions were re-enforced by Justice Sandra Day $\mathrm{O}^{\prime}$ Connor with her decision in Grutter v. Bollinger. ${ }^{29}$ These cases reflect much more than the Court's ambivalence, rather the dilemma of an entire society caught between two competing models of minority relations.

Current legal definitions of race and ethnicity thus reflect a profound ambivalence toward ethnic and racial classifications. Americans are caught between the model of individual justice implied by the non-discrimination model and the competing desire for a racially and ethnically just society. They deeply value the color-blind nondiscrimination model with its rejection of ethnic classifications as irrelevant and repugnant. And yet, valuing results, they recognize that a pluralistic society can only be achieved by effecting changes in the way minorities are represented in various sectors of American life. Classifying is, at best, a necessary evil. The need for aggregate solutions implies a need to classify; hence definitions are constructed. The definitions, however, are almost absurdly vague. Definitions phrased in terms of "origins in" an area reflect a discomfort with any but the most open-ended classifications. Even more indicative of this uneasiness is the insistence on self-identifications rather than the "objective" criteria of the early model (percentages of 
"blood," for example). In short, the imprecision of current definitions of race and ethnicity is entirely appropriate, reflecting as it does a pluralist society's well-grounded discomfort with classifying and categorizing the human population.

\section{Works Cited}

1 We have excluded Native Americans from this examination because laws and policies regarding them are quite different from other laws on race and ethnicity. For an introduction to this subject see Felix $\mathrm{S}$. Cohen, Handbook of Federal Indian Law (Albuquerque: University of New Mexico Press, 1971); Vine Deloria Jr. ed. American Indian Policy in the Twentieth Century (Norman, University of Oklahoma Press, 1985); Francis Paul Prucha, American Indian Policy in the Formative Years (Cambridge, Mass.: Harvard University Press, 1962); and, Charles F. Wilkinson, American Indians, Time and the Law: Historical Rights at the Bar of the Supreme Court (New Haven: Yale University Press, 1987).

2 See, for example, Winthrop D. Jordan, White Over Black: American Attitudes Toward the Negro, 1550-1812. (Chapel Hill: University of North Carolina Press, 1968), 104 - 139.

3 Louisiana courts have taken judicial cognizance of the following categories of color: Negro, _ Negro blood; griffe, _ mulatto; mulatto, Negro, _ white; quadroon, _ Negro, _ white; octoroon, $1 / 8$ Negro, $7 / \overline{8}$ white. In spite of these distinctions, those having 1/16 or more Negro blood were considered "persons of color." See Stetson Kennedy, The Jim Crow Guide to the USA (London: Lawrence and Wishart, 1959), 50. The Louisiana classification system was adopted from Saint Domingue. For its history see M.L.E. Moreau de Saint Mery, Description tographique, physique, civile, politique et historique de la partie francaise de l'lle de Saint-Domingue (Paris: Societe de I'Historie des Colonies Francaises, 1958), 96.

4 Carroll D. Wright, The History and Growth of the United States Census (Washington, D.C.: US Government Printing Office, 1900), 187.

5 Howard M. Bahr, Bruce A. Chadwick, Joseph H. Strauss, American Ethnicity (Lexington, Mass.: D.C. Heath and Company, 1979), 27-28. 


\section{Ethnic Studies Review Volume 26: 2}

6 See, for example, Helen T. Caterall, ed., Judicial Cases Concerning American Slavery and the Negro, 5 vols. (Washington, D.C.: Carnegie Institution, 1926-37), 2, 168; and Jordan, White Over Black, 168.

7 Plessy v. Ferguson, 163 US 537 (1896). Albion Tourgee's brief on behalf of Plessy in this case emphasizes this point.

8 Code of Alabama, Title I, § 2, "Meaning of Certain Words and Terms" (1940). This and other state laws regarding race are collected in Pauli Murray, States' Laws on Race and Color (Cincinnati: Women's Division of the Methodist Church, 1951), 19.

9 George Code Annotated, $\S \S 60-97$ (1943). Also Louisiana General Statutes § 1073 (1939), in Murray, 345 and 193-194, respectively.

10 Gong Lum v. Rice, 275 US 78 (1927).

11 North Carolina Revised Code, §§ 60-97 (1943). Also Louisiana General Statutes § 1073 (1939), Murray, 345 and 193-4, respectively.

12 Doe v Louisiana, Civ. District Court Orleans Parish Civ. Doc. (5) No. 78-9513 (1982).

13 Ozawa v. US, 260 US 178 (1922) and US v. Thind, 261 US 204 (1922). See also In re Ah Yup, 223 C.C.D. Cal. (1878). For an excellent discussion of the role of race in naturalization and immigration law see lan F. Haney Lopez, White By Law: The Legal Construction of Race (New York: New York University Press, 1996).

14 Morrison v. California, 291 US 82 (1934); In re Knight, 171 F. 299 (E.D.N.Y. 1909).

15 EEOC Guideline on Discrimination Because of Race, Fair Employment Practices Manual (Washington: Bureau of National Affairs).

16 The 1980 US Census definitions, for example, indicate that "origin and descent can be viewed as the ancestry, nationality group, lineage, or country in which the person or the person's parents or ancestors were born before their arrival in the United States." 1980 Census of Population: Supplementary Report on Age, Sex, Race and Spanish Origin of the Population, PC80-s1-1 (May 1981), 2.

18 Reprinted in B. Schlei and P. Grossman, Employment Discrimination Law (Washington, D.C.: Bureau of National Affairs, 1976), note 2 , supra, p. 246, n. 5. 
19 EEOC Guidelines on Discrimination Because of National Origin, 20 CFR 1606, 1 (1974).

20 See, for example, remarks of President Lyndon B. Johnson at Howard University, Washington, D.C., June 4, 1965, quoted in John Hope Franklin and Isidore Star, eds., The Negro in Twentieth Century America (New York: Random House, 1967), 225; also, Stephan Therstrom and Abigail Therstrom, America in Black and White: One Nation, Indivisible (New York, Simon and Schuster, 1997), 414. In the field of education, the notion of race-conscious solutions is first suggested in Green v. School Board of New Kent County, 391 US 430 (1968) and more explicitly in Swann v. Charlotte-Mecklenburg Board of Education, 403 US 913B (1971).

21 See Griggs v. Duke Power Company, 401 US 424 (1971) and Washington v. Davis, 426 US 229 (1976). This procedure, originally judicially formulated is now incorporated into the Federal Uniform Guidelines on Employment Selection: 'Procedures having adverse impact on members of any race, sex, or ethnic group will be considered discriminatory unless the procedure has been validated.' Uniform Guidelines on Employee Selection Procedures (Washington, D.C.: Government Printing Office, 1980), 21.

2242 USC § 1971 (1976) and Voting Rights Act of 1965 Amendments, June 23 1982, Pub. L. No. 97-205. See also The Voting Rights Act: Ten Years After (Washington: United States Commission on Civil Rights, 1975). On discriminatory impact, see White v. Register, 412 US 755 (1973); City of Mobile v. Bolden, 446 US 100 (1980); and Rome v. United States, 446 US 156 (1980).

231980 Census of Population: Supplementary Reports: Race of the Population by State, PC80-S1-3.

24 Federal Contract Compliance Manual (Washington: Bureau of National Affairs) 1:0004 $\S$ 1-60. The Manual suggests that this information can be obtained either by personal knowledge of the employer, or self-identification of the applicant.

25 Keyes v. School District No.1, 413 US 189 (1973).

26 Joseph Alegretti, "National Origin Discrimination and the Ethnic Employee," The Employee Relations Law Journal, 6: 4 (Spring 1981), 546.

27 United Jewish Organizations of Williamburgh, Inc. v. Carey, 430 US 144 (1977). An argument suggesting aggregate voting rights is made in Yale Law Journal Note, "United Jewish Organizations of Williamburgh, 


\section{Ethnic Studies Review Volume 26: 2}

Inc. v. Carey and the Need to Recognize Aggregate Voting Rights," 87 Yale Law Journal 571 (1978). This notion is refuted in "Note, Proportional Representation by Race: The Constitutionality of Benign Racial Redistricting," 74 Michigan Law Review 820 (1976).

28 Board of Regents of the University of California v. Bakke, 438 US 265 (1978).

29 Grutter v. Bollinger, 288 F. 3d 732 (2003). 